\title{
Introduction: a symposium on the predatory state
}

\author{
Mehrdad Vahabi ${ }^{1}$
}

Published online: 10 September 2019

(c) Springer Science+Business Media, LLC, part of Springer Nature 2019

\begin{abstract}
Economists have adopted two broad perspectives on the state: contractual (i.e., provider of public goods and services) and predatory (coercive and extractive). By a predatory state, we mean a state that promotes the private interests of dominant groups within the state (such as politicians, the army and bureaucrats) or influential private groups with strong lobbying powers. Neo-institutional economists support an extended version of the contractual perspective in which the state is not simply a 'benevolent dictator' but may itself be composed of predators. However, it considers predation as only a means to promote protection. By contrast, a predatory vision of the state argues that while protection and predation are two faces of the same coin, a predatory state protects only to promote its predation on the private sector. This symposium explores how a predatory approach to the state can shed light on all types of state, from liberal democratic to authoritarian and failed ones, both in the past and present.
\end{abstract}

Keywords Predatory state $\cdot$ Contractual state $\cdot$ Predatory welfare state $\cdot$ Passive and active predatory state $\cdot$ Wealth destroying states

JEL Classification $\mathrm{H} 1 \cdot \mathrm{H} 5 \cdot \mathrm{I} 3 \cdot \mathrm{L} 5 \cdot \mathrm{N} 4 \cdot \mathrm{O} 12 \cdot \mathrm{Z} 12$

Political scientists, sociologists and anthropologists have formulated a host of theories to explain the origins of the state. The richness of those theories notwithstanding, economists have adopted two broad approaches to studying the state in situ: contractual (i.e., a provider of public goods and services) and predatory (coercive and extractive).

Predation is closely related to coercive appropriation. In Sophist, Plato (2013, p. 27) already distinguished two types of techniques or crafts, one productive, creating its proper object, and the other extractive, based on coercive appropriation of what the others have produced. He wrote: "Let us define piracy, man-stealing, tyranny, the whole military art, by one name, as hunting with violence" (Plato 2013, p. 85). Following Plato, violent hunting or prey-predator relationships embrace all types of private and state predation.

Pareto (1971/1927, p. 341) repeated Plato when he stated: "The efforts of men are utilized in two different ways: they are directed to the production or transformation of

Mehrdad Vahabi

mehrdad.vahabi@wanadoo.fr

1 CEPN, University Paris 13, Villetaneuse, France 
economic goods, or else to the appropriation of goods produced by others." Thus, violence has the double face of Janus: protective and predatory (Tilly 1985). The former enhances production, the latter hinders production but promotes coercive extraction. How do contractual and predatory approaches to the state capture its protective and predatory aspects?

Hobbes's (2019/1651) Leviathan provides a first formulation of the contractual approach to the state, defining the 'rights of nature' as every means available to individuals for the purpose of self-preservation in a war of all against all. The result is anarchy, in which life will be "solitary, poor, nasty, brutish and short". Accordingly, the "goal of reason" should be to cease perpetual war and build a stable society, which requires the abandonment of individuals' "natural rights" and the investment of power in a sovereign body, or Leviathan, to safeguard lives and property. Government thus is a solution to anarchy, but what should be done about Leviathan's unrestrained predatory powers? According to Smith (1961/1776, vol. II, book IV), while the state may be needed to avoid anarchy or to control private predation, state predation also must be controlled by narrowing Leviathan's functions to those of a 'night-watchman', i.e., a state that protects human rights and property rights, provides defense against external invasions, and supplies public goods.

A simple version of the contractual approach is advocated by mainstream economists adopting a "public-good provider" perspective on the state, conceived as being governed by a benevolent dictator who maximizes the citizenry's collective interest (Samuelson 1954; Musgrave and Musgrave 1973). The intervention of such a state is sought whenever market failure is present.

The definition of a predatory state often is limited to a state that does not protect private property rights and hinders economic development. By a predatory state, we mean a state that "would specify a set of property rights that maximized the revenue of the group in power, regardless of its impact on the wealth of the society as a whole" (North 1981, p. 22). It would promote the private interests of dominant groups inside the state (such as politicians, the army and bureaucrats) or influential private groups with effective lobbying powers (Leeson et al. 2019; Vahabi et al. 2019).

Neo-institutional economists support an extended version of a contractual perspective (Buchanan 1999/1962) in which the state is not simply a 'benevolent dictator' but may be composed of predators. However, they emphasize three features of predatory activity:

A. Contractual rationales for predation The first line of reasoning deals with predation as a form of implicit transaction similar to any other form of 'voluntary' interaction. It extends the meanings of "voluntary exchange" and "mutual gain from trade" far beyond their usual connotations. According to the Political Coase Theorem (an extension of Coasean bargaining to coercive relationships), involuntary transactions can be treated as if they are voluntary (see Vahabi 2011; Shughart II and Thomas 2014; Munger 2019). For example, from that perspective a robbery can be defined as an "implicit contract" between victim and robber, in which the robber agrees not to kill the victim in return for a certain amount of money. In reaction to the extension of Coasean bargaining to a "coercive exchange", Olson (2000, p. 3) wrote: "For our focus on coercive power and our analysis of self-interested behavior, I use a criminal metaphor. Clearly, we cannot understand robbery as either a voluntary trade or a moral act, and thus it helps us to focus only on the selfinterested use of coercive power."

B. Everyone is a predator A bandit, a revolutionary, a rebel or a tyrant all are assumed to be a looter (predator) or a potential looter; only losers in conflict are labeled as 'prey'. Thus, predation is not always (or only) a relationship between predator and prey. As a 
matter of fact, the founders of our discipline ${ }^{1}$ grasped predation as a particular relationship between the predator (tyranny) and prey (merchants, industrialists and financers) by referring to the role of 'capital flight' in restraining tyranny during early modernity (see Hirschman 1970, 1978). Since prey can be tracked down by predator, it needs to flee (exit) or resist (voice) to survive.

C. Positive rent seeking A contractual vision of the state does not always exclude the predatory interests of state officials and entrepreneurs, but it deems that predators may turn into protectors if they collect enough protection rents. The rent is not necessarily negative or welfare-reducing, but can be positive or welfare-enhancing (North et al. 2009, 2013). Predatory violence can be managed or domesticated in return for the rents granted by entrepreneurs to state officials. While that conclusion is contradictory to Buchanan's view of rent seeking as being intrinsically negative, it is compatible with his distinction between a protective/productive state and a predatory state (Buchanan 1975).

In summary, a contractual vision of the state, while acknowledging predation, considers predation as only a means of promoting protection. By contrast, an appropriative vision of the state argues that while protection and predation are two faces of the same coin, $a$ predatory state protects only to promote its predation. A predatory vision of the state provides an explanation for the protection afforded by predators under the following three circumstances.

A. Domestication to limit the exit option of prey In a multiple-predatory system characterized by several predators competing with each other for prey, one predator can monopolize a "protection racket", thereby gaining exclusive access to prey by protecting them from other predators. That is the basic principle of domestication as a technology of domination. A tyrant in competition with other tyrants needs to avoid capital flight by protecting certain property rights that limit capital's exit (Vahabi 2016a, chap. 2). Hence, every predator also must incur the costs of safeguarding prey against potential threats from other predators. State predation will be more effective and efficient when the price of protection is low, and the quality of protection is high, thus providing a rationale for interjurisdictional tax competition à la Tiebout (1956).

B. Maximizing the state's revenue Production requires protection of property rights to secure long-term investment. As Buchanan (1975) and Holcombe (1994, pp. 8-9, 2004, pp. 329-330) explain, the ruler is motivated to protect his subjects since he obtains more income from their productive activities than from pillaging them once for all. Olson (1982) also emphasized the differences between roving and stationary bandits. The time horizon of the ruler is the determinant of choosing either simple predation or domestication. The former is based solely on the use of force (aggression) for occasional pillaging and marauding. By contrast, the latter requires a combination of protection and aggression to develop the prey's long-run productive capacity.

C. Political stability Maximizing the state's revenue needs long-term political stability, which can be achieved if the incumbent's power is not threatened by rebellious subjects. The protection of certain rights is a way to economize on the costs of keeping the prey in

\footnotetext{
1 Hirschman $(1970,1978)$ emphasized the incompleteness of limiting the description of predation as a relationship between predator and prey. For example, he provided many excerpts from Montesquieu, Sir James Stuart Mill and Adam Smith in which they defined money, notes, bills of exchange, stocks of companies, ships, all commodities and merchandises as 'movable assets' capable of fleeing from tyranny's control. He (1978, p. 98) also cited Turgot regarding the role of the emigration of persons in addition to capital in enhancing democracy. For a detailed discussion of that point, see Vahabi (2016a, b).
} 
captivity. Loyal subjects are much less costly than rebellious ones. Benson (1999, p. 152) summarizes the point eloquently: "After all, the more secure the sovereign feels, the longer his time horizon tends to be, and this in turn implies secure private property rights.' 'For the same reason, Levi (1988, pp. 13, 32-33) emphasized that "revenue" promotes the interests of predators in the long run, but that 'rules' constrain predation.

A major challenge for a predatory perspective of the state is to explain how a liberal democratic state that offers social welfare protection can be predatory. Could a welfare state also be predatory? Is predatory behavior limited only to failed states and authoritarian political regimes? The first four papers in this issue tackle that problem, focusing on liberal democracies in advanced capitalist economies.

Vahabi et al. (2019) examine welfare states, their emergence and development after the Second World War. They show that the relationship between 'protection' and 'predation' of welfare states is not dichotomous. Their line of argument is based on what they call a 'total war effect' according to which the welfare state is an outcome of modern mass (total) warfare. The total war economy requires the participation of all citizens, erasing the differences between the military and citizens. Consequently, a war economy benefits from succoring the civilian population, albeit often imposing rationing and other privations on them. The total war effect explains why a predatory state undertakes welfare programs. Accordingly, the authors coin the expression "predatory welfare state". But can one counterfactually imagine a welfare system without a welfare state? Vahabi, Batifoulier and Da Silva describe an alternative non-predatory welfare system, called la sociale in French, which emerged as a citizen welfare program during Paris Commune in 1871. La sociale, or citizen welfare, reappeared in the aftermath of the Second World War as a direct consequence of French resistance to the Fascist occupation. The authors compare and contrast citizen welfare (la sociale) with a predatory welfare state (Etat social). The term 're-appropriation effect, explains the process by which citizen welfare was replaced by a welfare state (Etat social) during the course of a series of reforms adopted in 1946, 1967 and 1996. Vahabi, Batifoulier and Da Silva also refer to the American experience of fraternal social welfare organizations predating the New Deal and the rise of the welfare state there, and ask whether the state re-appropriation effect was at work in other parts of the world.

Leeson et al. (2019) also treat all types of state, including a liberal democratic one, as predatory. However, they suggest a distinction between a 'passive' and an 'active' predatory state. An active predatory government suppresses political competitors or expropriates citizens' property. Leeson (2007), Leeson and Williamson (2009) and Boettke and Leeson (2015, p. 22) previously have called such states 'ultra-predatory'. In contrast, a passive predatory government serves as a vehicle for private parties' particularistic designs on one another-the suppression of their marketplace competitors or diversion of fellow citizens' incomes to themselves. A regulatory state in liberal democracies is a passive predatory state. The authors examine public regulation of 'quack medicine' in nineteenth-century England. Such medicines were prepackaged, marketed concoctions brewed from "secret recipes" that frequently contained powerful drugs, e.g., opium, strychnine and chloroform. State regulation consisted in establishing health professional monopoly on sale of "scheduled poisons" since 1870 to get rid of Medicinal anarchy. While according to conventional wisdom, this initiative was taken to protect public health, the authors argue that medical professionals (namely licensed physicians and licensed chemists and druggists) used state to prey on competitors. To show the shortcomings of a public goods approach, the authors highlight the level of medicinal knowledge at the time. Minimal understanding of illness and how to treat was widespread until 1890. When knowledge is minimal, people self-treat. Quack med vendor thus becomes close substitute for health professional and threatens 
health professional rents. The rationale for passive predatory state is demonstrated by underlining the need to lobby government to establish a monopoly of drug dispensing and thereby protect their rents.

Holcombe (2019) examines the rationale for protection within a predatory vision of the state. He explores the impact of ideology, particularly "progressive democracy", as a means of making predation less costly (to the predators) in modern states. His starting point is how to reduce the costs of predation by persuading their prey that they are not prey. If citizens perceive themselves as prey, they will resist the predatory state and will not produce much that the state can appropriate. The predatory state will be more successful if it can convince its citizens that the state's activities are undertaken in the public's interest, which will enhance voluntary compliance with the state's mandates and lessen the state's need to allocate resources to overt coercion. The ideology of "progressive democracy" encourages citizens to cooperate with the state and legitimizes the state's predatory activities. According to Holcombe, the ideology of Progressivism justifies the imposition of costs on some for the benefit of others. The ideology of democracy implies that when a democratic government does so, it is acting into promote the general welfare.

Benson (2019) also focuses on predatory nature of liberal democracies or what North et al. (2009) call "open access orders". He introduces a reinterpretation of North et al. compatible with a predatory vision of the state. His arguments aim to show why the neoinstitutional perspective does not support conceiving of the state as a provider of public goods; rather, it is more consistent with a predatory vision of the state. While Benson concedes that states do provide public goods, the primary focus of politicians appears to be on transferring wealth to themselves, to elites and interest groups, or both. Most states also have engaged in aggression to expand their jurisdictions. Predatory-state theories focuses on wealth transfers and aggression. As such, the models explain states' historical development and many observed state actions. Perhaps surprisingly, they even provide a theoretical explanation for public-good provision. The primary conclusion of Benson's paper is that states, including the United States, are predatory. Consideration of violence, organizations, institutions and beliefs adds power to that contention. Observed state institutions and organizations are consistent with an evolved predatory state. Examination of a number of explicit or implicit institutional and organizational assumptions supporting public-interest views of states further reinforces the contention. Those assumptions either do not hold, or hold only in part.

A second series of papers explore different types of predatory states in the context of economic development. The contributors distinguish between welfare-degrading (destroying) and welfare-enhancing predatory states. The focus of the included studies is not on liberal democracies, but rather on authoritarian or failed states. Post-socialist Russia and Afghanistan are offered as two salient illustrations of welfare-degrading (destroying) predatory states.

Boettke and Candela (2019) reconsider Buchanan's discussion of protective/productive versus predatory states and pose the "paradox of being governed". Consistent with Boettke and Leeson (2015), they argue that to resolve that paradox requires endowing the state with the capacity to secure the institutional conditions for economic development, while constraining it from preying on its own citizenry. The authors then raise the question: What are the conditions that divide states into those that constrain or enable predation? Answering that question, the authors reconceptualize and unbundle the relationships among public predation, state capacity and economic development from a constitutional perspective. State capacity emerges from an institutional context in which the state is constrained from predating on its citizenry in violation of predefined rules limiting its discretion. When 
constraints limiting political discretion are not in place, state capacity will degenerate from a means of delivering economic development to a means of predation. Applying their theoretical framework, the authors investigate two case studies of economic and political transition: the privatization of Russia after the collapse of the Soviet Union circa 1989; and the political unification of Sicily with the Italian peninsula following the Napoleonic Wars. In both cases, political and economic transitions intended to secure well-defined and wellenforced property rights, but which in large part redistributed those rights, augmented the predatory capacity of the state.

Murtazashvili and Murtazashvili (2019) distinguish two types of wealth-destroying and wealth-creating predatory states. In doing so, they analyze the mechanisms that supply incentives for the state to create rather than destroy wealth. First, political stability matters: rulers are more likely to choose policies that create wealth and maintain control over their territories. Second, the extent of predation depends on the effectiveness of political constraints, especially separation of powers and political decentralization. Third, the extent to which self-governing organizations constrain predation depends on whether they themselves are predatory. Finally, at least three types of foreign intervention influence the scope of the predatory state: foreign aid, colonialism and foreign military presence. Foreign aid and colonialism each can contribute to wealth destruction by relaxing budget constraints on predatory rulers and also by undermining institutional constraints on rulers. A foreign military presence is in some instances a source of corruption and patronage that also makes it easier for the specialist in coercion (and monopolist of it) to expropriate wealth from ordinary citizens. The authors marshal historical and fieldwork evidence from Afghanistan to illustrate the logic of wealth-destroying states.

A third series of papers investigate the relationship between religion and predation. While Skaperdas and Vaidya (2019) discuss the theoretical relationship between 'Big-God' religions and 'for-profit' states, Kuran (2019) elucidates how an Islamic fiscal tool, i.e., Zakat, could limit predatory taxation.

Skaperdas and Vaidya (2019) construct a theoretical model to study the historical relationship between Big-God religions and predatory states that they call 'for-profit' states. According to them, over the past two millennia successful pre-modern states in Eurasia adopted and cultivated Big-God religions emphasizing (1) the ruler's legitimacy as divinely ordained and (2) a morality adapted for large-scale societies that can have positive economic effects. Relying on extensive historical research, they establish a link between such religions and pre-modern states, seeing both as maximizing the ruler's profit. They model the interactions of rulers and subjects who enjoy both material and psychological payoffs, the latter emanating from religious identity. Overall, religion reduces the need to control subjects by resorting to threats of violence, increases production, increases tax revenue, and reduces banditry. A Big-God ruler, who also is a believer, has stronger incentives to invest in expanding the number of believers and their intensities of belief, as well as investing in state capacity. Furthermore, such investments often are complementary, mutually reinforcing one another, and leading to the attractiveness and evolutionary advantage of rulers that adopt Big-God religions.

Islam might be considered to represent a Big-God religion. However, Kuran (2019) argues that Zakat could have prevented the emergence of a predatory Islamic state. He starts by explaining Zakat as one of Islam's five canonical pillars, namely a predictable, fixed, mildly progressive tax system that had to be paid annually. It was meant to finance various causes typical of a pre-modern government. Implicit in the entire transfer system were personal property rights as well as constraints on government-two key elements of a liberal order. Those features could have provided the starting point for 
broadening political liberties under a state with explicitly restricted functions. Instead, barely a few decades after Muhammad declared himself a "prophet of Allah" in 610 $\mathrm{CE}$, the door was opened to arbitrary governance and material insecurity. States ruling under Islamic law have been able to prey on their subjects more or less with impunity. According to Kuran, a major reason for such a radical change was that the Quran did not make explicit the underlying principles of governance. It simply outlined the specifics of Zakat as they related to conditions in seventh-century Arabia.

A major characteristic of this special issue is the pride of place that it grants to studying the history from an interdisciplinary/political economy viewpoint. Most of the papers in the issue draw on historical evidence and identify different economic and social patterns and regularities without assuming any predetermined historical "laws". Although historical references are provided throughout the issue, two papers devote their attention specifically to the origins and variety of predatory states in the past. One is contributed by Arslantaş et al. (2019), the other by Svendsen (2019).

Arslantaş et al. (2019) provide a comparative fiscal study of the Ottoman Empire in contradistinction with the Western Europe. While the Western scheme of fiscal state is characterized by a transition from a decentralized to a centralized order traversing through different phases of tribute states, domain states, tax states and fiscal states, the Ottoman Empire fiscal system is marked by (1) decentralization, and (2) the use of confiscatory measures or müsadere. While in France since 1681, tax-farming was unified in a single, quasi-private organization known as the Company of General Farms, taxfarming under the Ottoman Empire became more decentralized during the eighteenth century. The possibility of collective action by French tax-farmers strengthened their powers of resisting the King's pressures to collect more taxes when necessary, one of the triggers of the French Revolution. By contrast, the more decentralized Ottoman Empire relied on routine confiscation (müsadere). That system enhanced political performance by maintaining the Sultan's power and averting revolution, but it caused economic impoverishment since local elites were encouraged to invest in fugitive, but less productive, assets (Vahabi 2016a, b). The müsadere system was used either as punishment or more generally as post mortem seizure of the property from fiscal elites. Borrowing from a thorough historical analysis based on first-hand documents (Arslantaş 2018) and distinguishing between 'captive' and 'fugitive' assets (Vahabi 2016a, b), the authors explore theoretically the impact of the Ottoman fiscal system on the Empire's economic performance and political stability during the long eighteenth century.

Svendsen (2019) substantiates the origins of Viking Age England on the basis of Olson's model of roving versus stationary bandits. As argued theoretically by him (Olson 1993), an economically rational raider may transform into a ruler when it pays to do so. The author asks when raiders will become rulers in a predatory state by focusing on the intriguing case of Viking Age England. Here, written records do exist and they show how local English kings were not able to protect their areas of influence against competing Viking raiders. Defense was, however, eventually supplied by the strongest military leader among the Vikings, namely Cnut the Great. He switched from raiding England with his father, Swein Forkbeard, to monopolizing violence and started taxing the local citizens in return for protection against himself and other Vikings. Svendsen shows how revenue was maximized by a system of different tax payments and that Cnut acted rationally when switching from raider to ruler. Producing rather than fighting was now possible as a result of effective defense, enforcement of property rights and institutionalized tax systems, thus too serving the overall economic interests of England. 
Finally, the last group of papers by McGuire (2019) and Crettez (2019) discusses the issue of predation at a purely theoretical level.

McGuire (2019) employs a diagrammatic analysis to review some of the results explored in the literature dealing with conflict and trade while dispensing with the familiar Ricardo-Edgeworth framework. The starting point is not a pure Ricardian model of trade based on comparative advantages, since trade and raid (predation) are assumed to be at work concurrently. Borrowing from Garfinkel and Syropoulos (2017), McGuire develops a basic model of predatory states in which he tries to capture how incentives to trade interact with those of predation. The model's primary purpose is heuristic: to assemble the components of Ricardo and present them in a manner that specifically incorporates opportunities for appropriation by armed conflict. McGuire shows how the component working parts fit together and, what is more important, builds the simplest possible model to state his case. The main result of the paper is that trade and predation are independent. Another novelty of the paper is McGuire's use of a diagrammatic analysis, eschewing a contest success function resting on strong behavioral assumptions.

Crettez (2019) introduces Pareto-minimality in the jungle. The author extends Piccione-Rubinstein's (2007) model of a jungle economy model when the power relation is not necessarily asymmetric. There are as many agents as goods; agents consume at most one indivisible good. The model assumes a strong transitive power relation. In Crettez's modified setup, the strongest agent takes the best allocation, the second strongest the second best, and the weakest the worst allocation. The model first asks whether wild jungle equilibria are Pareto-minimal. An allocation is defined as Pareto-minimal if it is impossible to reduce the welfare of one agent without increasing the welfare of another. It is shown that jungle equilibria are not necessarily Pareto-minimal. Crettez studies and characterizes the set of Pareto-minimal jungle equilibria. He then tackles the case wherein people can be equally powerful, in contrast to the assumption that the power relation is asymmetric. Assuming a transitive weak power relation, it is demonstrated that jungle equilibria exist, but they are not always unique, nor Pareto-optimal. The paper also verifies conditions under which the equilibria are Pareto minimal.

It is noteworthy that half of the papers in this special issue have been presented in an international symposium in Paris on the 'Predatory State' organized by CEPN (University Paris 13) on May 20, 2019.

\section{References}

Arslantaş, Y. (2018). Confiscation by the ruler: A study of the Ottoman practice of Müsadere, 1700-1839. (Unpublished doctoral dissertation). London School of Economics and Political Science, London.

Arslantaş, Y., Pietri, A., \& Vahabi, M. (2019). State predation in historical perspective: the case of Ottoman Müsadere practice during 1695-1839. Public Choice. https://doi.org/10.1007/s11127-019-00700-9.

Benson, B. (1999). An economic theory of the evolution of governance and the emergence of the state. Review of Austrian Economics, 12, 131-160.

Benson, B. (2019). The development and evolution of predatory-state institutions and organizations: Beliefs, violence, conquest, coercion, and rent seeking. Public Choice. https://doi.org/10.1007/s11127-01900667-7.

Boettke, P., \& Candela, R. (2019). Productive specialization, peaceful cooperation, and the problem of the predatory state: Lessons from comparative historical political economy. Public Choice. https://doi. org/10.1007/s11127-019-00657-9.

Boettke, P., \& Leeson, P. (2015). Introduction. In P. Boettke \& P. Leeson (Eds.), The economic role of the state. Cheltenham: Edward Elgar. 
Buchanan, J. (1975). The limits of liberty: Between anarchy and leviathan. Chicago: University of Chicago Press.

Buchanan, J. M. (1999/1962). The collected works of James M. Buchanan. The calculus of consent: Logical foundations of constitutional democracy (Vol. 3). Indianapolis: Liberty Fund.

Crettez, B. (2019). Pareto-minimality in the jungle. Public Choice. https://doi.org/10.1007/s11127-01900677-5.

Garfinkel, M., \& Syropolous, C. (2017). Trading with the enemy. Memo of March 1, 2017, Department of Economics, University of California-Irvine, Irvine, CA.

Hirschman, A. O. (1970). Exit, voice, and loyalty. Cambridge, MA: Cambridge University Press.

Hirschman, A. O. (1978). Exit, voice, and the state. World Politics, 31(1), 90-107.

Hobbes, T. (2019/1651). Leviathan or the matter, forme, and power of a common-wealth ecclesiastical and civil. http://socserv.mcmaster.ca/econ/ugcm/3113/hobbes/Leviathan.pdf.

Holcombe, R. (1994). The economic foundations of government. New York: New York University Press.

Holcombe, R. (2004). Government: Unnecessary but inevitable. Independent Review, 8(3), 325-342.

Holcombe, R. (2019). Progressive democracy: The ideology of the modern predatory state. Public Choice. https://doi.org/10.1007/s11127-019-00637-z.

Kuran, T. (2019). Zakat: Islam's missed opportunity to limit predatory taxation. Public Choice. https://doi. org/10.1007/s11127-019-00663-x.

Leeson, P. (2007). Better off stateless: Somalia before and after government collapse. Journal of Comparative Economics, 35(4), 689-710.

Leeson, P., King, S., \& Fegley, T. (2019). Regulating quack medicine. Public Choice. https://doi. org/10.1007/s11127-019-00656-w.

Leeson, P., \& Williamson, C. (2009). Anarchy and development: An application of the theory of second best. Law and Development Review, 2(1), 77-96.

Levi, M. (1988). Of rule and revenue. Berkeley: University of California Press.

McGuire, M. (2019). Trade and the predatory state: Ricardian exchange with armed competition for resources: A diagrammatic exposition. Public Choice. https://doi.org/10.1007/s11127-019-00672-w.

Munger, M. (2019). Tullock and the welfare costs of corruption: There is a "political Coase Theorem". Public Choice, 181(1-2), 83-100.

Murtazashvili, J., \& Murtazashvili, I. (2019). Wealth-destroying states. Public Choice. https://doi. org/10.1007/s11127-019-00675-7.

Musgrave, R., \& Musgrave, P. (1973). Public finance in theory and practice (1st ed.). New York: McGraw Hill.

North, D. (1981). Structure and change in economic history. New York: W.W. Norton and Company.

North, D., Wallis, J., Webb, S., \& Weingast, B. (Eds.). (2013). In the shadow of violence: Politics, economics, and the problems of development. Cambridge: Cambridge University Press.

North, D., Wallis, J., \& Weingast, B. (2009). Violence and social orders: A conceptual framework for interpreting recorded human history. New York: Cambridge University Press.

Olson, M. (1982). The rise and decline of nations: Economic growth, stagflation, and social rigidities. New Haven: Yale University Press.

Olson, M. (1993). Dictatorship, democracy, and development. American Political Science Review, 87, $567-576$.

Olson, M. (2000). Power and prosperity, outgrowing communist and capitalist dictatorships. New York: Basic Books.

Pareto, V. (1971/1927). Manual of political economy. New York: A.M. Kelley.

Piccione, M., \& Rubinstein, A. (2007). Equilibrium in the jungle. Economic Journal, 117(522), 883-896.

Plato. (2013). Sophist. Translated by Benjamin Jowett, Hazelton, PA., An Electronic Classics Series Publication. http://www2.hn.psu.edu/faculty/jmanis/plato/sophist.pdf.

Samuelson, P. (1954). The pure theory of public expenditure. Review of Economics and Statistics, 36(4), 387-389.

Shughart, W. F., II, \& Thomas, D. W. (2014). What did economists do? Euvoluntary, voluntary, and coercive institutions for collective action. Southern Economic Journal, 80(4), 926-937.

Skaperdas, S., \& Vaidya, S. (2019). Why did pre-modern states adopt Big-God religions? Public Choice. https://doi.org/10.1007/s11127-019-00681-9.

Smith, A. (1961/1776). An inquiry into the nature and causes of the wealth of nations. London: Methuen.

Svendsen, G. (2019). Two bandits or more? The case of Viking Age England. Public Choice. https://doi. org/10.1007/s11127-019-00707-2.

Tiebout, C. H. (1956). A pure theory of local expenditures. Journal of Political Economy, 64(5), 416-424.

Tilly, C. (1985). War making and state making as organized crime. In P. Evans, D. Rueschemeyer, \& T. Skocpol (Eds.), Bringing the state back in (pp. 169-191). Cambridge: Cambridge University Press. 
Vahabi, M. (2011). Appropriation, violent enforcement and transaction costs: A critical survey. Public Choice, 147(1), 227-253.

Vahabi, M. (2016a). The political economy of predation: Manhunting and the economics of escape. New York: Cambridge University Press.

Vahabi, M. (2016b). A positive theory of predatory state. Public Choice, 168(3-4), 153-175.

Vahabi, M., Batifoulier, P., \& Da Silva, N. (2019). A theory of predatory welfare state and citizen welfare: The French case. Public Choice. https://doi.org/10.1007/s11127-019-00660-0.

Publisher's Note Springer Nature remains neutral with regard to jurisdictional claims in published maps and institutional affiliations. 